\title{
Bronchoscopy during the COVID-19 pandemic: A survey study
}

\author{
COVID-19 pandemisinde bronkoskopi: Bir anket çalışması
}

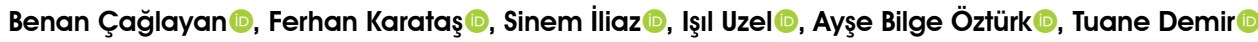 \\ Department of Chest Diseases, Koç University, School of Medicine, Istanbul, Turkey
}

\begin{abstract}
Background: In this study, we aimed to evaluate the attitudes and behaviors of physicians performing bronchoscopy during the COVID-19 outbreak.

Methods: Between March 2020 and May 2020, a total of 153 physicians were included in the study. An invitation letter for the participation in the study with a structured questionnaire of 18 questions were sent to the mail groups twice with five-day intervals. Participation in the study was allowed, until the third day after the second mail was sent.
\end{abstract}

Results: All participants completed the questionnaire. According to the results, $33 \%$ of the physicians did not perform bronchoscopy and the majority of the physicians performed very few procedures during the outbreak, although the participants mostly worked at the tertiary hospitals (mean: 7.2 \pm 9.3 ). A total of $20 \%$ of the physicians performed bronchoscopy in potential or proven COVID-19 patients. Almost all of the physicians who participated in the survey reported the use of personal protective equipment such as masks and goggles during the procedure. During the pandemic, $9.7 \%$ of the physicians who performed bronchoscopy to potential or proven COVID-19 patients and $4.1 \%$ of the participants who did not perform bronchoscopy to any potential or proven COVID-19 patients were found to be infected with the virus $(\mathrm{p}>0.05)$.

Conclusion: Physicians who perform bronchoscopy during pandemic act in accordance with the recommendations of guidelines. Although there was no statistically significant difference between the SARS-CoV-2 transmission rates of the teams who performed and did not perform bronchoscopy in potential or proven COVID-19 patients in our study, the high rate of personal protective equipment utilization might have played a role in this result.

Keywords: Bronchoscopy, COVID-19, endobronchial ultrasound, outbreak, SARS-CoV-2.

\section{$\ddot{O} Z$}

Amaç: Bu çalışmada, COVID-19 salgını sırasında bronkoskopi yapan hekimlerin tutum ve davranışları değerlendirildi.

Çalışma planı: Mart 2020 - Mayıs 2020 tarihleri arasında, toplam 153 hekim çalışmaya alındı. Mail gruplarına beş gün aralıklarla iki kere 18 sorudan oluşan yapılandırılmış anket ile katılım davet mektubu gönderildi. İkinci mail gönderiminden sonra üçüncü güne kadar çalışmaya katılıma izin verildi.

Bulgular: Katılımcıların tümü anketi tamamladı. Sonuçlara göre, katılımcılar büyük ölçüde üçüncü basamak hastanelerde çalışmakla birlikte, hekimlerin \%33'ü salgın sırasında bronkoskopi yapmadı ve büyük bir çoğunluğu çok az sayıda

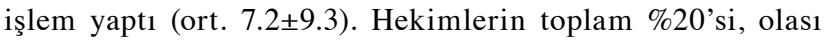
veya kesin COVID-19 hastalarına bronkoskopi yaptı. Ankete katılan hekimlerin neredeyse tamamı, işlem sırasında maske ve gözlük gibi kişisel koruyucu ekipman kullandığını bildirdi. Pandemi sırasında olası veya kesin COVID-19 hastalarına bronkoskopi yapan hekimlerin \%9.7'si ve olası veya kesin COVID-19 hastalarının hiçbirine bronkoskopi yapmayan hekimlerin \%4.1'inin virüs ile enfekte olduğu saptand $1(\mathrm{p}>0.05)$.

Sonuç: Bronkoskopi yapan hekimler, salgın sırasında kılavuz önerilerine uygun bir biçimde hareket etmektedir. Çalışmamızda olası veya kesin COVID-19 hastalarına bronkoskopi yapan ve yapmayan hekimlerin ekiplerindeki SARS-CoV-2 bulaş oranları istatistiksel olarak anlamlı düzeyde farklı olmamakla birlikte, kişisel koruyucu ekipman kullanımının bu sonuçlarda

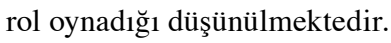

Anahtar sözcükler: Bronkoskopi, COVID-19, endobronşiyal ultrason, salgin, SARS-CoV-2.

Received: June 20, 2020 Accepted: July 19, 2020 Published online: April 26, 2021

Correspondence: Benan Çağlayan, MD. Koç Üniversitesi Tıp Fakültesi, Göğüs Hastalıkları Anabilim Dalı, 34010 Zeytinburnu, İstanbul, Türkiye. Tel: +90 532 - 2810378 e-mail: benancag@gmail.com 
Severe acute respiratory syndrome coronavirus-2 (SARS-CoV-2), the virus responsible for novel coronavirus 2019 (COVID-19) infection, has rapidly spread all over the world after being first described in Wuhan province of China in late December 2019 and was declared as a pandemic by the World Health Organization (WHO) in March $2020{ }^{[1]}$ After the Republic of Turkey, Ministry of Health reported the first case of COVID-19 on March $11^{\text {th }}, 2020$, the disease spread rapidly in our country. According to the data of the Ministry of Health on May $16^{\text {th }}$, 2020, which was at the time of our study conduction, the number of the cases which tested positive for SARS-CoV-2 reverse transcriptase-deoxyribonucleic acid (RT-DNA) polymerase chain reaction (PCR) was 148,067 and the number of individuals who died from COVID-19 was $4,096 .^{[2]}$ Due to its rapid spread and high mortality, the disease affects both the individual and social life seriously.

The virus primarily contaminates the surfaces which infected individuals are contacted with and spreads via the droplets by the infected individuals. The transmission occurs from the infected person to the others through the respiratory or oral route. It is known that the asymptomatic COVID-19 patients are also a potential source of the virus and they can infect other individuals. Some procedures such as bronchoscopy, tracheostomy, or endotracheal intubation cause aerosolization which increases the transmission risk for the healthcare professionals (HCPs).$^{[3,4]}$ Although there is no study which proves to show a reduction in the risk of transmission to HCPs during bronchoscopy, some guidelines have been published. According to these guidelines, narrowing the indications for bronchoscopy, minimization of the number of personnel involved in the process, utilization of the personal protective equipment (PPE) during the procedure, and preference of the flexible bronchoscopy instead of the rigid bronchoscopy are recommended to reduce the risk of transmission..$^{[5-7]}$

In the present study, we aimed to evaluate the attitudes and behaviors of physicians performing bronchoscopy in Turkey during the COVID-19 outbreak.

\section{PATIENTS AND METHODS}

Between 11.03.2020 and 15.05.2020, a total of 153 physicians were included in the study. A structured questionnaire was developed and sent via e-mail to all members of three different thoracic societies of our country.
In eight of 18 questions in the questionnaire, the participants were asked to choose only one answer choice. Nine questions in the questionnaire allowed to choose more than one answer choice (Appendix 1). In one question, the participants were asked the number of procedures performed throughout the study period. At the beginning of the questionnaire, baseline data regarding the specialty (chest physician [CP] or thoracic surgeon [TS]), the institutions where they worked, experience level of the participants in the bronchoscopy procedure, and setting of the hospital at which the participants worked were collected.

The questionnaire involved several steps of the patient management in the participants' practice including the diagnosis of the patients, indications for bronchoscopy, methods of the anesthesia and bronchoscopy, preparation for procedure and features of the operation room, and extent of PPE. The participants were also asked whether they performed bronchoscopy during the COVID-19 outbreak. If they had, they were asked whether there were any infected personnel in their teams.

The structured questionnaire was first tested by the researchers on the web. An invitation letter for the participation in the study with a structured questionnaire of 18 questions were sent to the mail groups twice with five-day intervals. Participation in the study was allowed, until the third day after the second mail was sent. The study protocol was approved by the Koç University Ethics Committee (Date: 19.02.2021-No: 2021.071.IRB3.032). The study was conducted in accordance with the principles of the Declaration of Helsinki.

\section{Statistical analysis}

Statistical analysis was performed using the IBM SPSS for Windows version 26.0 software (IBM Corp, Armonk, NY, USA). Descriptive data were expressed in mean \pm standard deviation (SD), median (min-max), or number and frequency. Comparison of categorical variables were performed using the chi-square and Fisher's exact tests. A $p$ value of $<0.05$ was considered statistically significant.

\section{RESULTS}

A total of 153 participants completed the survey including 129 CPs (84.3\%) and 24 (TSs). Of the physicians, $73.9 \%$ were performing bronchoscopy for more than 10 years, $12.4 \%$ for 5 to 10 years, and $13.7 \%$ for less than five years. Most of the participants (86.3\%) were experienced bronchoscopists with $>5$ years of experience. Of 153 respondents, 105 (68.6\%) were 
Table 1. Behaviors and attitudes of participating physicians on bronchoscopy during pandemic and the rate of personal protective equipment usage

\begin{tabular}{lc}
\hline Parameters & $\%$ \\
\hline Participants performing bronchoscopy & 20.3 \\
Participants who didn't perform bronchoscopy & 79.7 \\
Transmission of the disease & 7.9 \\
Transmission to those who performed & 9.7 \\
bronchoscopy to the COVID-19 patient & \\
Transmission to those who didn’t perform & 4.1 \\
bronchoscopy to the COVID-19 patient & \\
Flexible bronchoscopy & 95.1 \\
Rigid bronchoscopy & 16.7 \\
Endobronchial ultrasonography & 20.6 \\
Interventional & 6.9 \\
Negative pressured room & 18.6 \\
No revision of unit & 36.3 \\
Used of UV lamp & 18.6 \\
Higher level of disinfection & 52 \\
Usage N95/FFP2 mask & 98 \\
Usage eye glass/face sheet & 96 \\
Usage protective gown & 73.7 \\
Usage of cap & 74.7 \\
Minimum staff & 65.7 \\
\hline COVID-19: Coronavirus 2019; UV: Ultraviolet. &
\end{tabular}

working either in a training and research hospital or a university hospital, i.e. in the tertiary setting. Of the remaining respondents, $10.5 \%$ were working in a state hospital and $20.9 \%$ were working in a private hospital.

According to the survey responses, $33.3 \%$ of the physicians did not perform any bronchoscopy during the study period during the outbreak. When TSs and CPs were analyzed separately, $83.3 \%$ of TSs and $63.6 \%$ of CPs continued to perform bronchoscopy during this period $(p=0.059)$. With regard to the levels of the hospitals, bronchoscopy procedures were maintained at the rate of $68.6 \%$ in the tertiary hospitals, $62.5 \%$ in the secondary hospitals, and $81.3 \%$ in the private hospitals $(p=0.001)$. When the reasons for not performing bronchoscopy during the pandemic were questioned, $52.9 \%$ of the participants reported that it was due to the administrative decision, 33.3\% showed the physical conditions of the bronchoscopy unit not being suitable as the reason, and $49 \%$ avoided to put themselves and their team at risk. Only one of the respondents reported PPE being inaccessible as the reason.

Of 153 physicians, $31(20.3 \%)$ performed bronchoscopy to probable or proven COVID-19 patients. In addition, COVID-19 infection was seen in the team of three $(9.7 \%)$ physicians who performed bronchoscopy to a probable or proven COVID-19 patient. On the other hand, COVID-19 was seen among the team of five $(4.1 \%)$ physicians who did not perform bronchoscopy $(\mathrm{p}=0.21)$. The difference was not statistically significant. Among the participants who continued to perform bronchoscopy in the pandemic, the incidence of SARS-CoV-2 infection in the teams

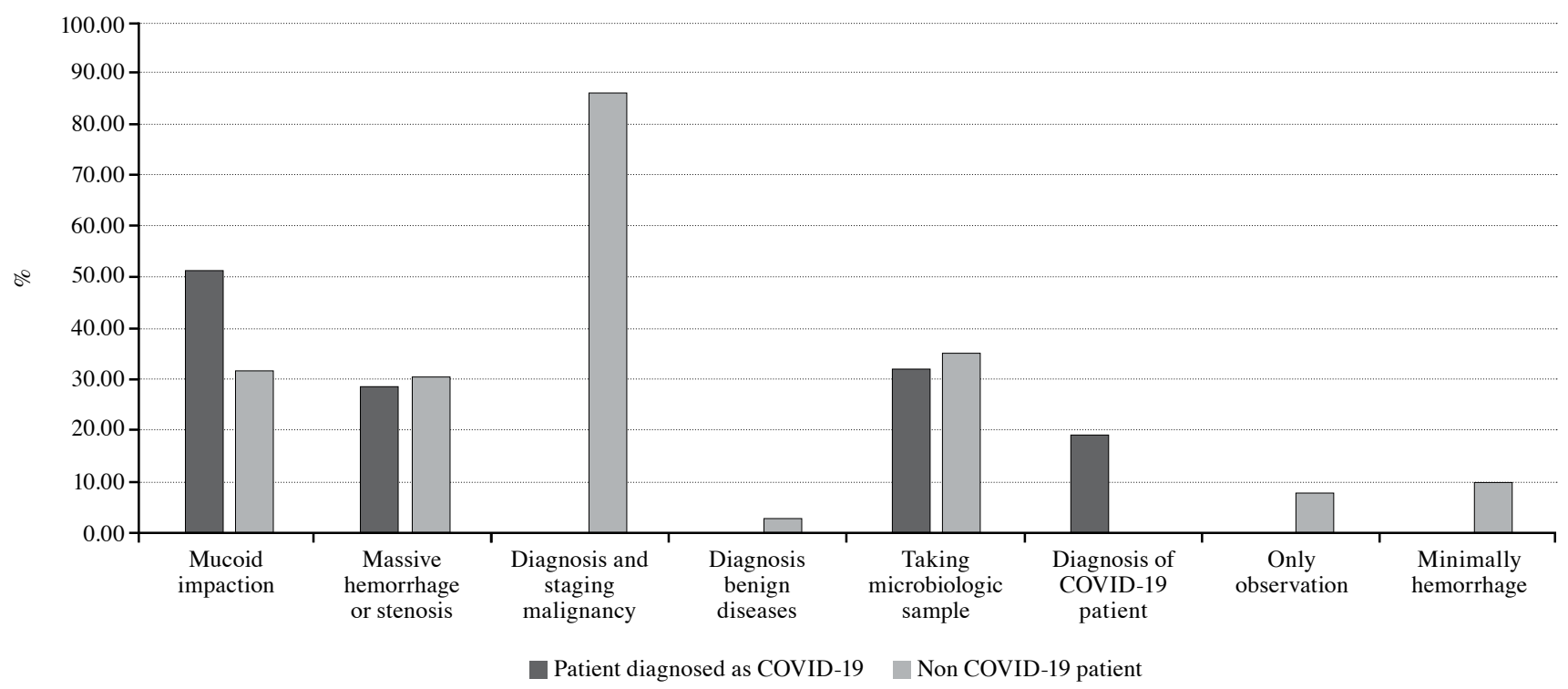

Figure 1. Indications of bronchoscopy during pandemic.

COVID-19: Coronavirus 2019. 


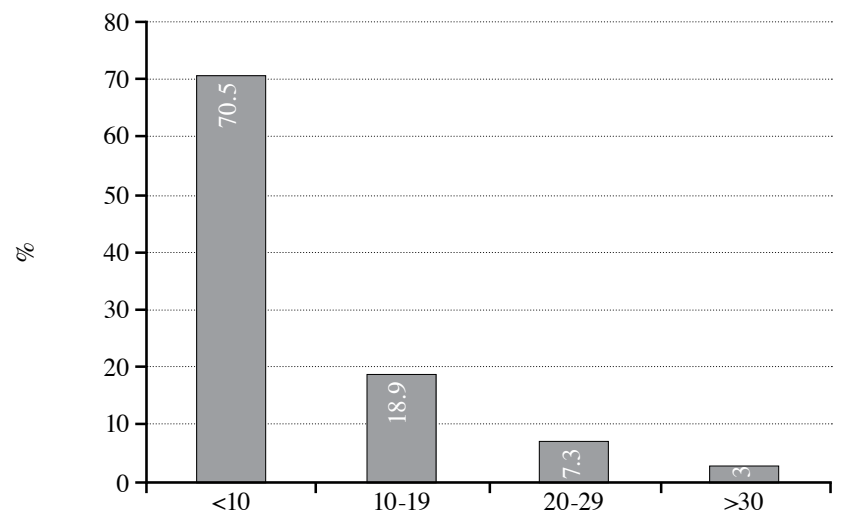

Figure 2. Distribution of number of bronchoscopies performed during pandemic.

was $7.9 \%$ (Table 1). The majority of the respondents had COVID-19 inpatient service (94.1\%) and COVID-19 outpatient clinics $(88.1 \%)$ in their hospitals.

According to the indications for bronchoscopy in COVID-19 patients, $51.6 \%$ used bronchoscopy to clean the mucous plugs, $32.3 \%$ to collect a microbiological sample, $19.4 \%$ to confirm the diagnosis of COVID-19, and $29 \%$ for the interventional purposes. This question was answered by all the physicians who performed bronchoscopy in COVID-19 patients (Figure 1).

Diagnosis and staging of a malignant disease were the leading indications for bronchoscopy in cases other than COVID-19 (86.3\%). Bronchoscopy performed for the diagnosis of the benign diseases constituted a very small ratio (2.9\%) during this period. On the other hand, bronchoscopy was used for the microbiological studies in $35.3 \%$ of the procedures. Treatment of emergencies such as cleaning of the mucous plugs, bleeding, and stenosis was an indication for a significant number of bronchoscopy procedures (53.5\%). In addition, 45\% of the TSs who continued to perform bronchoscopy reported that preoperative observation was the main purpose of the procedure (Figure 1).

A total of 102 physicians answered the question about the bronchoscopy methods used during this period and $95.1 \%$ of them used the flexible bronchoscopy, $16.7 \%$ used the rigid bronchoscopy, and $20.6 \%$ used the endobronchial ultrasound (EBUS) (Table 1). According to the distribution among the physicians, 12 TSs and five CPs performed the rigid bronchoscopy with eight of 12 TSs and all of five CPs using it for the interventional purposes.

To evaluate a probable COVID-19 infection in a patient before bronchoscopy, $88.2 \%$ of the physicians questioned fever and other COVID-19 symptoms, 81.4\% COVID-19 contact, and $69.6 \%$ traveling abroad. Sampling for RT-DNA PCR before the procedure and getting a thoracic computed tomography (CT) $24 \mathrm{~h}$ beforehand were done at a ratio of $50 \%$ and $47.1 \%$, respectively.

During the study period, the ratio of the physicians who preferred general anesthesia was $27.5 \%$, while the ratio of those who preferred the topical anesthesia was $25.5 \%$. The rate of the physicians who chose to perform a deeper sedation compared to their past practices was $22.5 \%$.

Totally, 98 physicians performed very few procedures during the pandemic, although these

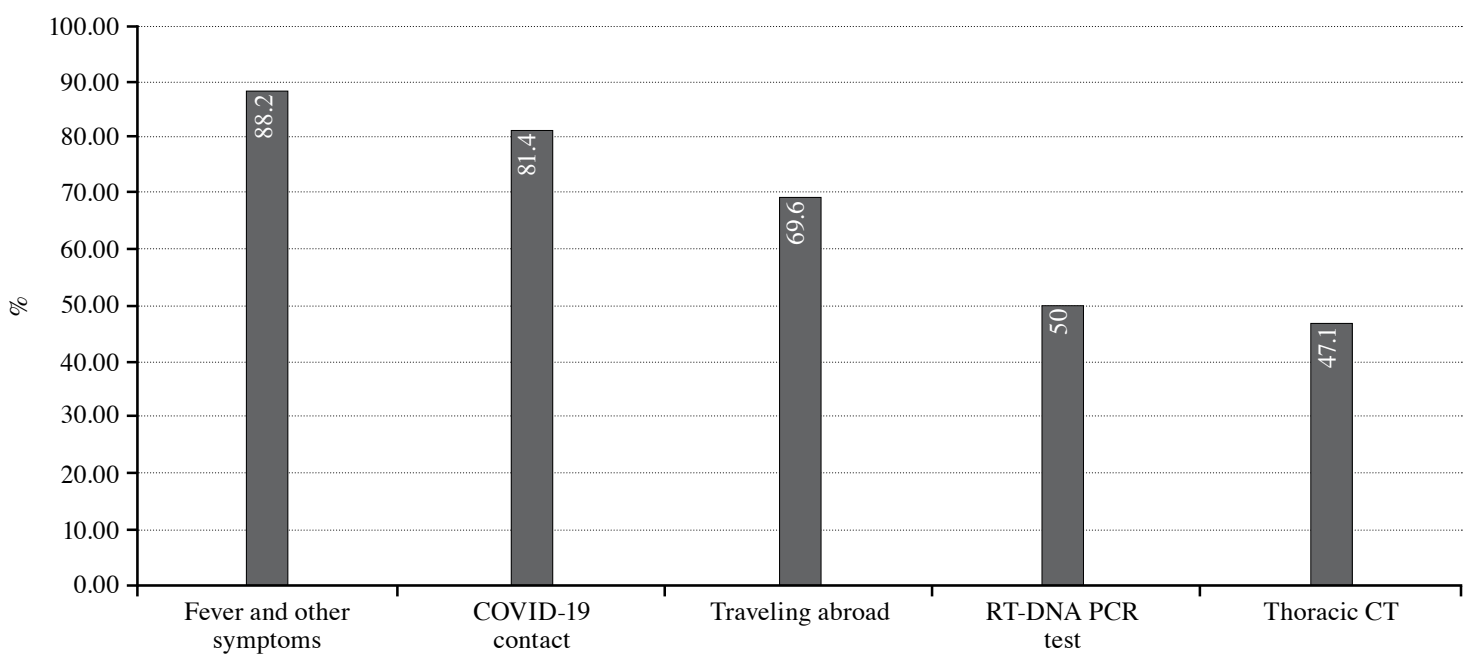

Figure 3. Screening methods for COVID-19 before procedure.

RT: Reverse transcriptase; DNA: Deoxyribonucleic acid; PCR: Polymerase chain reaction; CT: Computed tomography; COVID-19: Coronavirus 2019. 
participants mostly worked at the tertiary hospitals

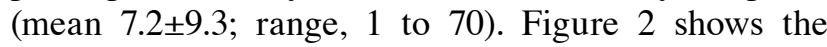
distribution among the physicians according to the number of procedures performed.

There was no revision of the bronchoscopy unit used by $36.3 \%$ of the physicians who participated in the survey. Bronchoscopy was performed in the negative-pressure room by $18.6 \%$ of the participants, and the rate of those who started to use the ultraviolet lamps in the bronchoscopy unit were $18.6 \%$. In addition, $52 \%$ of the participants reported that the cleaning and disinfection of the bronchoscopy room started to be done at a higher level, compared to the past.

In our study, the vast majority of the participants paid a particular attention to the use of PPE (Table 1). Also, $65.7 \%$ of the participants reduced the number of staff working in the team to minimize the risk of transmission.

\section{DISCUSSION}

In the present study, we evaluated the compliance of the physicians who performed bronchoscopy in Turkey during SARS-CoV-2 pandemic to the national and international guidelines. Our study results showed that $33 \%$ of the participants did not perform bronchoscopy during the pandemic and the ones who performed significantly decreased the number of procedures they performed. On the other hand, $20 \%$ of the participants performed bronchoscopy to the proven or probable COVID-19 patients. Almost all of the physicians who participated in the survey used the personal protective equipment such as masks and goggles during the procedure. During the pandemic, 9.7\% of the participants who performed bronchoscopy to probable or proven COVID-19 patients and $4.1 \%$ of the participants who did not perform bronchoscopy to any probable or proven COVID-19 patients were found to be infected $(p>0.05)$. It was not possible to identify whether the infection was directly related to bronchoscopy, since all the infected teams also had a COVID-19 service in their hospitals. Altogether, we concluded that the attitudes and behaviors of physicians performing bronchoscopy in our country were largely in consistent with the recommendations of the national or international guidelines.

Although all HCPs are at risk for the infection by the SARS-CoV-2 virus, aerosol-producing bronchoscopy increases this risk and the consequences may be more serious. To reduce the risk, taking a swab sample for the RT-DNA PCR test from the patient prior to the procedure and/or using PPE are seen as two basic strategies. Another method is to postpone bronchoscopy for two weeks and isolate the patient during this period of time, if there is no emergent situation. The current guidelines suggest postponing bronchoscopy for elective purposes. ${ }^{[6-14]}$ In our study, $33 \%$ of the respondents did not perform bronchoscopy during the pandemic, while the remaining participants performed a very few number of bronchoscopy. The ratio of bronchoscopy performed for the diagnostic purposes was very low in benign cases. These results showed that elective cases were postponed throughout the study period. According to the recommendations, bronchoscopy should not be seen as the first-line diagnostic tool in probable COVID-19 cases and this procedure should be avoided as much as possible..$^{[6,9,15]}$ However, bronchoscopy should be performed in the patients tested negative for the RT-DNA PCR and for whom the treatment strategy would change in the presence of an alternative diagnosis. Bronchoscopy should be also performed to obtain a microbiological sample in the presence of a coinfection and to clear the tracheobronchial secretions in the presence of an atelectasis. ${ }^{[15]}$ In addition, massive bleeding, foreign body aspirations, and tracheal stenosis are the indications for bronchoscopy in COVID-19 patients. ${ }^{[6]}$ Torrego et al. ${ }^{[15]}$ reported that indications for bronchoscopy were probable coinfection in 63 and airway secretion management with and without atelectasis in 38 of 101 bronchoscopies performed in 93 COVID-19 patients. In our study, the vast majority of the physicians did not perform bronchoscopy, while $51.6 \%$ of the physicians performed bronchoscopy in COVID-19 patients for the management of the excessive secretions. In addition, $32.3 \%$ physicians performed bronchoscopy to collect a microbiological sample.

Pritchett et al. ${ }^{[6]}$ suggests that bronchoscopy should be performed within one to two days in an immunocompromised patient who does not respond to empirical antibiotic treatment. In case of a malignancy, bronchoscopy for the diagnostic and/or staging purposes should be performed after two weeks. In cancer patients, postponing bronchoscopy to an uncertain day is not recommended. In the same guideline, it is recommended that emergent interventional bronchoscopy procedures should be performed on the same day without a delay. In our study, many of bronchoscopy indications in cases other than COVID-19 were the diagnosis and staging of a malignancy (86.3\%). Considering bronchoscopies for obtaining microbiological samples in a separate category, only three of 102 participants (2.9\%) reported that they performed bronchoscopy for the 
diagnosis of sarcoidosis or other benign diseases. In our study, emergent situations such as atelectasis due to the mucous plugs, massive hemorrhage, foreign body aspiration, and tracheal stenosis were the main indications for $53.5 \%$ of the participants performing bronchoscopy, while $35.3 \%$ performed bronchoscopy for taking a microbiological sample.

Prior to bronchoscopy, evaluation of patients regarding COVID-19 infection is important for the diagnosis. Therefore, fever and other symptoms, contact with a COVID-19 patient, and history of traveling abroad should be questioned. On the day of the procedure, the body temperature should be measured and symptoms of COVID-19 should be questioned again. The RT-DNA PCR testing and postponement of the procedure are recommended for cases who are considered a probable COVID-19 patient after this screening. ${ }^{[6,9,13,16]}$ In the American College of Chest Physicians (CHEST)/American Association for Bronchology and Interventional Pulmonology (AABIP) guidelines, it is recommended to perform RT-DNA PCR test in all asymptomatic cases before bronchoscopy, if applicable. ${ }^{[5]}$ In our study, questioning the symptoms such as fever and COVID-19 contact were performed at a high rate $(88.2 \%$ and $81.4 \%$ respectively). The RT-DNA PCR test before the procedure was performed in $50 \%$ of the procedures. Although thoracic CT $24 \mathrm{~h}$ before the procedure is not recommended by the guidelines, $47.1 \%$ of the respondents performed thoracic CT in our study.

Bronchoscopy staff who do not use N95 masks and other PPE have been reported to be infected during the influenza and SARS outbreaks. ${ }^{[6]}$ Therefore, the use of PPE such as the N95/FFP2 masks, goggles/face shield, gown and gloves is recommended in all guidelines. ${ }^{[5-10,12-14]}$ In our study, we observed that the participants were careful about the use of PPE. The rate of N95 or FFP2 mask use was $98 \%$, and the rate of use of goggles or face shield was $96 \%$. The rates of gown and cap use were $73.7 \%$ and $74.7 \%$, respectively. To reduce the risk of contamination, keeping the number of individuals in the team in the operation room to a minimum, not using a nebulizer prior to the procedure, performing deeper sedation to suppress the cough reflex, preferring the flexible bronchoscopy instead of the rigid bronchoscopy, and utilizing closed ventilation systems instead of jet ventilation, if general anesthesia is applied are recommended. Performing bronchoscopy in a negative-pressure room is recommended by the guidelines to reduce the transmission risk of the infection..$^{[6,9,13,14]}$ In our study, the ratio of bronchoscopy performed in a negativepressure room was found to be low (18.6\%). During the pandemic, flexible bronchoscopy was preferred more; however, particularly CPs preferred the rigid bronchoscopy for the interventional procedures. About two-thirds of the physicians participating in the study reduced the number of staff in their bronchoscopy team during the pandemic.

The low number of thoracic surgeons included in the study is the main limitation.

In conclusion, our colleagues who perform bronchoscopy in our country are mostly compliant to the recommendations of the current national and international guidelines on this subject. Although there was no statistically significant difference between the SARS-CoV-2 transmission rates of the teams who performed and did not perform bronchoscopy in potential or proven COVID-19 patients in our study, the high rate of personal protective equipment utilization might have played a role in this result.

\section{Declaration of conflicting interests}

The authors declared no conflicts of interest with respect to the authorship and/or publication of this article.

\section{Funding}

The authors received no financial support for the research and/or authorship of this article.

\section{REFERENCES}

1. Hur J, Chang MC. Usefulness of an Online Preliminary Questionnaire under the COVID-19 Pandemic. J Med Syst 2020;44:116.

2. Türkiye Cumhuriyeti Sağlık Bakanlığı, COVID-19, yeni korona virüs hastalığı. Available at: https://covid19bilgi. saglik.gov.tr/tr/ [Accessed: May 29, 2020]

3. Tran K, Cimon K, Severn M, Pessoa-Silva C, Conly J. Aerosol-generating procedures and risk of transmission of acute respiratory infections: a systematic review. CADTH Technol Overv 2013;3:e3201.

4. Wilson NM, Norton A, Young FP, Collins DW. Airborne transmission of severe acute respiratory syndrome coronavirus-2 to healthcare workers: a narrative review. Anaesthesia 2020;75:1086-95.

5. Wahidi MM, Shojaee S, Lamb CR, Ost D, Maldonado F, Eapen G, Caroff DA, et al. The Use of Bronchoscopy During the Coronavirus Disease 2019 Pandemic: CHEST/AABIP Guideline and Expert Panel Report. Chest 2020:S00123692(20)30850-3.

6. Pritchett MA, Oberg CL, Belanger A, De Cardenas J, Cheng G, Nacheli GC, et al. Society for Advanced Bronchoscopy Consensus Statement and Guidelines for bronchoscopy and airway management amid the COVID-19 pandemic. J Thorac Dis 2020;12:1781-98. 
7. Lentz RJ, Colt H. Summarizing societal guidelines regarding bronchoscopy during the COVID-19 pandemic. Respirology 2020;25:574-7.

8. Group of Interventional Respiratory Medicine, Chinese Thoracic Society. Expert consensus for bronchoscopy during the epidemic of 2019 Novel Coronavirus infection (Trial version). Zhonghua Jie He He Hu Xi Za Zhi 2020;43:E006.

9. Wahidi MM, Lamb C, Murgu S, Musani A, Shojaee S, Sachdeva A, et al. American Association for Bronchology and Interventional Pulmonology (AABIP) Statement on the Use of Bronchoscopy and Respiratory Specimen Collection in Patients with Suspected or Confirmed COVID-19 Infection [published online ahead of print, 2020 Mar 18]. J Bronchology Interv Pulmonol 2020;10.1097/LBR.0000000000000681.

10. Darwiche K, Ross B, Gesierich W, Petermann C, Huebner RH, Grah C, et al. Empfehlungen zur Durchführung einer Bronchoskopie in Zeiten der COVID-19-Pandemie [Recommendations for Performing Bronchoscopy in Times of the COVID-19 Pandemic]. Pneumologie 2020;74:260-2.

11. Ost DE. Bronchoscopy in the Age of COVID-19. J Bronchology Interv Pulmonol 2020;27:160-2.
12. Cordovilla R, Álvarez S, Llanos L, Nuñez Ares A, Cases Viedma E, Díaz-Pérez D, et al. SEPAR and AEER consensus recommendations on the Use of Bronchoscopy and Airway Sampling in Patients with Suspected or Confirmed COVID-19 Infection. Arch Bronconeumol 2020;56 Suppl 2:19-26.

13. Luo F, Darwiche K, Singh S, Torrego A, Steinfort DP, Gasparini S, et al. Performing bronchoscopy in times of the COVID-19 pandemic: practice statement from an 1nternational expert panel. Respiration 2020;99:417-22.

14. Türk Toraks Derneği'nin COVID-19 Pandemisi Süresince Bronkoskopi Yapılırken ve Sonrasında Alınacak Önlemler Hakkında Önerileri. Available at: https://www.toraks.org.tr/ subNews.aspx?sub=185\&notice $=5817$ [Accessed: May 29, 2020]

15. Torrego A, Pajares V, Fernández-Arias C, Vera P, Mancebo J. Bronchoscopy in patients with COVID-19 with invasive mechanical ventilation: A single-center experience. Am J Respir Crit Care Med 2020;202:284-7.

16. Steinfort DP, Herth FJF, Irving LB, Nguyen PT. Safe performance of diagnostic bronchoscopy/EBUS during the SARS-CoV-2 pandemic. Respirology 2020;25:703-8. 


\section{Appendix 1}

1. The institution that you work in:
a. Private Hospital
b. Government Hospital
c. Education and Research Hospital
d. University Hospital

2. Your specialty:
a. Chest diseases
b. Thoracic surgery
c. Intensive care unit

3. For how long have you been performing bronchoscopy?
a. 0-5 years
b. 5-10 years
c. Over 10 years

4. Have you continued to perform bronchoscopy during the COVID period (After the $11^{\text {th }}$ of March) ? If your answer is No, you can conclude the survey by answering only the next question.
a. Yes
b. No

5. What is your reason of not performing bronchoscopy during the COVID period? (You can choose more than one option)

a. The decision of the hospital or the clinic administration

b. Not being provided by a personal protective equipment

c. Bronchoscopy unit not being suitable

d. To avoid any risk exposure to myself and/or the other personnel

6. Have you performed bronchoscopy on a potential COVID patient or on a patient with definitive COVID diagnosis?
a. Yes
b. No

7. If you have performed bronchoscopy on a definite or a potential COVID patient, what was the indication for the bronchoscopy? (You can choose more than one option)
a. Mucous plug-atelectasis
b. To take a microbiological sample
c. To confirm the diagnosis
d. Emergency situations such as hemorrhage or stenosis

8. What was the indication for the bronchoscopy in non-COVID cases? (You can choose more than one option)
a. Staging or diagnosis of a malignancy
b. To take a microbiological sample
c. In a case suspicious for tuberculosis, to take a sample for acid fast stain
d. To clear the mucous plugs
e. Emergency situations such as hemorrhage or stenosis
f. To make a diagnosis for benign diseases
g. Minimal hemoptysis
h. For evaluation before an operation

9. Which bronchoscopy methods have you used during this period? (You can choose more than one option)
a. Flexible bronchoscopy
b. Rigid bronchoscopy
c. Interventional bronchoscopy
d. EBUS

10. Which of the below have you performed routinely before a bronchoscopy procedure in non-COVID patients? (You can choose more than one option)

a. Questioning fever and other symptoms

b. Questioning recent international travel

c. Questioning contact with a COVID patient

d. Taking a sample for COVID rt-PCR

e. Getting a chest CT before the procedure (within 24 hours)

11. Have you changed the anesthesia method that you use during the COVID period? (You can choose more than one option)

a. Yes, I started to prefer general anesthesia.

b. Yes, I started to prefer topical anesthesia and sedation.

c. I started to prefer deeper sedation.

d. I started not using nebulization.

12. Has there any change done in your bronchoscopy unit during this period? (You can choose more than one option)

a. No change has been done.

b. Yes, there has been a switch to the negative-pressured room.

c. The level of disinfection and cleaning of the room has been increased.

d. Sterilization with UV-lamb has been started.

13. Has your personal protective equipment changed during this period? (You can choose more than one option)
a. Yes, I started to wear a N95/FFP2 mask.
b. Yes, I started to wear gloves and a visor.
c. Yes, I started to wear a protective coat.
d. Yes, I started to wear a surgical cap.
e. No, I already have been doing all these things.
f. No, I don't use a special equipment.

14. Have you declined the number of personnel in your team present while performing bronchoscopy during this period?

a. Yes

b. No

15. Have you or has anyone in your bronchoscopy team been infected with SARS-COV-2?
a. Yes
b. No

16. How many bronchoscopy procedures have you performed approximately during this period?

17. Do you have COVID outpatient clinic in your hospital?
a. Yes
b. No

18. Have COVID patients been treated in inpatient service in your hospital?

a. Yes

b. No

COVID-19: Coronavirus 2019; EBUS: Endobronchial ultrasonography; RT: Reverse transcriptase; PCR: Polymerase chain reaction; CT: Computed tomography; SARS-CoV-2: Severe acute respiratory syndrome coronavirus-2. 